\title{
'ENTERAS DE AGUA, LAS CIUDADES': UNA NUEVA POÉTICA URBANA EN ZURITA
}

\author{
'ENTERAS DE AGUA, LAS CIUDADES': A NEW URBAN \\ POETICS IN ZURITA
}

\section{EVA VALERO JUAN*}

\section{RESUMEN}

En 2007 Raúl Zurita publicó Las ciudades de agua, poemario en el que sorprendió a sus lectores con un cambio espacial en el capítulo que lleva el título del libro: de los espacios de la naturaleza chilena, esenciales de su poesía previa, nos conduce a espacios urbanos que poetiza con absoluta originalidad. Con su mirada eternamente permeada de naturaleza, Zurita construye estas ciudades "de agua" sobre las que realizo una propuesta de lectura en este artículo. Los poemas analizados fueron trasvasados por el poeta a su último libro, Zurita (2011), donde se encuentran otras poetizaciones de espacios urbanos. Con todas ellas Raúl Zurita configura, en el siglo XXI, una nueva poética de la ciudad.

Palabras clave: Zurita, poesía, ciudad, naturaleza, agua.

\section{ABSTRACT}

In 2007 Raúl Zurita published Las ciudades de agua. In the chapter that gives name to this book of poems, Zurita surprised his public with a change of scenery. Thus, from Chilean nature, essential in his previous poetry, the author moves to urban landscapes, which are poeticized in a completely original manner. With his particular gaze, eternally permeated by nature, Zurita builds these cities "of water" which I shall analyse in this article. The author included these poems in his last book, Zurita (2011), as well as

* Doctora en Filología Hispánica. Profesora Titular de Literatura Hispanoamericana. Universidad de Alicante, Alicante (España).Correo: eva.valero@ua.es 
other poems about urban spaces. In all of them, Raúl Zurita shapes a new urban poetics for the $21^{\text {st }}$ Century.

Keywords: Zurita, poetry, city, nature, water.

Recibido: 22.11.13. Aceptado: 20.01.14.

Mira el río de las estrellas

trazando las ciudades en el decolado amanecer nuevoamericano

ZurITA, La vida nueva

$\mathrm{R}$

EFLEXIONAR SOBRE LA OBRA poética de Raúl Zurita es un acto en el que el mismo nombre del escritor parece imponer un destino: la dar esta obra en sus otras vertientes temáticas -la memoria histórica chilena, la experiencia del amor (su dolor y su plenitud), o el sufrimiento de la humanidad-obliga, en todos los casos, a pasar por las vastas cordilleras, los indecibles acantilados, los mares infinitos, los cielos-espejo del mundo... La naturaleza es, en la poesía del chileno, una presencia absoluta, que no funciona como telón de fondo, sino como gran protagonista poética en su dimensión más humana y totalizante:

... al ir leyendo los poemas -escribe José Carlos Rovira-, notamos que la naturaleza es amor, y violencia, y movimiento, comprendemos que la naturaleza consigue reflejar un vivir con sus pasiones y sus muertes, como el de los seres humanos; logra reflejar una forma de alma universal... (Rovira, 2011: 90).

Con esta dimensión -que José Carlos Rovira (2011) ha reconstruido en la trayectoria poética del escritor a través de la idea de "obra en progreso"encontramos la abrumadora presencia de la naturaleza, en diálogo constante con la cultura, desde Purgatorio (1979) y Anteparaíso (1982), pasando por El amor de Chile (1987), La vida nueva (1994) y su Canto de los ríos que se aman (1997), hasta las obras que Zurita publica ya en el nuevo siglo. Entre ellas se encuentra un título distinto, y desconcertante por la redirección espacial que indica y contiene, Las ciudades de agua, poemario publicado en 2007 con este título que induce al lector a pensar que Zurita dio en él un salto imprevisto en relación a los espacios en que habita su poesía: de la naturaleza a la ciudad. Podríamos decir que así es en cierta medida, sobre todo en la parte del poemario que lleva el título del libro ("Las ciudades de 
agua"), en la que el poeta nos conduce a ese espacio casi inexplorado en su obra que es la ciudad ${ }^{1}$. Sin embargo, basta introducirse en los poemas para comprobar que la naturaleza permanece, incluso, en las visiones poéticas de la ciudad. Es precisamente por esa filtración de las claves poéticas previas en la nueva poesía del espacio urbano que estas ciudades no van a ser meros escenarios citadinos, ni siquiera espacios poéticos interiores propios de la literatura urbana moderna que generó, desde el siglo XIX, tópicos como el del flâneur, o el de la "ciudad muerta", o el de "la ciudad como estado de ánimo". Zurita sorprende al lector de ciudades con una poética urbana inédita. Y lo consigue a través de su mirada eternamente permeada de naturaleza, de la que surgen estas ciudades sobre las que se cimentan las siguientes páginas.

\section{¿CIUDADES DE AGUA?}

Mi propuesta no puede comenzar sino por lo elemental: la reflexión sobre este título-Las ciudades de agua-, y sobre su aparente contradicción interna, pues la idea de ciudad está presidida, ante todo, y a pesar de la mutación constante que la define, por lo sólido, que permite el crecimiento y la expansión sobre los espacios de la naturaleza. Su esencia, a priori, diríamos que es lo pétreo, pero basta pensar, o ver -mirar- en las ciudades, para descubrir también su esencia opuesta, lo líquidoº: la ciudad es en sí misma, a veces inadvertidamente, un gran espacio reflectante. Efectivamente, son múltiples las superficies que espejean la vida que en ellas transcurre; imágenes que componen la idea de la ciudad líquida en todos los reflejos que la mirada distraída extravía, pero que nos rodea en cada uno de los rincones y elementos que la conforman, superponiendo imágenes (y por tanto también vidas) aquí y allá: en las vidrieras de los escaparates reflejando la vida

\footnotetext{
${ }^{1}$ En La vida nueva Zurita anticipa algunas visiones urbanas como por ejemplo las que encontramos en el poema "Las nuevas ciudades", que ya "brillan destellando" en un cielo de "infinitos puntos": "Mira el río de las estrellas trazando las ciudades en el decolado amanecer nuevoamericano" (Zurita, 1994: 435).

${ }^{2}$ El concepto de "lo líquido" aplicado a la ciudad ha sido teorizado, desde diferentes puntos de vista, por Manuel Delgado Ruiz en Ciudad líquida, ciudad interrumpida. La urbs contra la polis (1999) desde la perspectiva de la antropología; y por Zygmunt Bauman, en su obra Modernidad líquida (2002 [2000]) desde el punto de vista del fin de la modernidad sólida y con la propuesta de la metáfora de la liquidez para la fase actual de la modernidad. En Las ciudades de agua, sin embargo, no encontramos una plasmación poética de esta metáfora de lo líquido urbano aplicada al proceso de la modernidad, sino una construcción poética que remite a una imagen interior del poeta plasmada en un mundo urbano de reflejos y superposiciones, permeado de naturaleza.
}

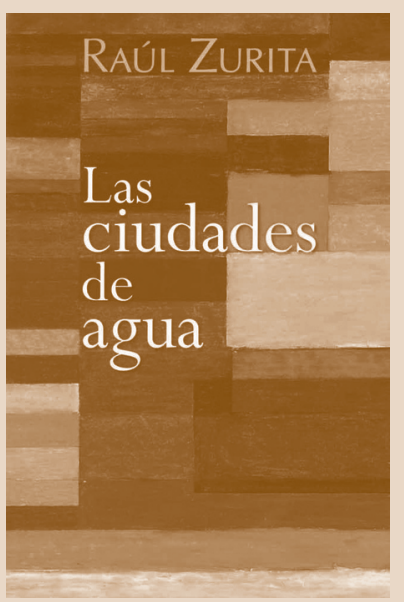

17 \begin{tabular}{|c|} 
Atenea 511 \\
\cline { 2 - 2 } I Sem. 2015
\end{tabular} 
que pasa; en los charcos o en las calles mojadas por la lluvia que contienen la ciudad de arriba; en los cristales de los vehículos e incluso en su superficie reflejando las nubes, el cielo, las casas, los rascacielos; en los ventanales de los edificios, o en los edificios de cristal que proyectan edificios dentro de edificios (vidas sobre vidas); e, incluso, en los ojos de quienes buscan estos reflejos ("las ciudades de agua en tus ojos"', escribe Zurita). Reflejos, en definitiva, que funden en un mismo punto de enfoque varias capas de paisajes que al tiempo pueden ser muchas vidas insertas en una misma imagen.

Añadamos que si el agua es el elemento primordial y primigenio de la naturaleza que produce el reflejo, la ciudad también es "de agua" tanto desde su esencia espejeante, como si ponemos el punto de mira en sus imágenes reflejadas en las más diversas superficies, desdibujadas en todos sus contornos, fragmentadas, borrosas; acuosas, en definitiva. En este sentido, resulta esencial recurrir a una obra fundamental para cualquier acercamiento a la poética de los espacios en relación con la esencia líquida: El agua y los sueños de Gastón Bachelard, ensayo en el que el filósofo reflexiona sobre "los poetas del agua" (de los que Zurita es un representante por antonomasia), del agua como "sustancia" de las ensoñaciones (que se concreta en los poemas de "Las ciudades de agua", presididas como veremos por la ensoñación), y "del pensamiento de las aguas" (esencial en la obra completa del poeta chileno):

...si logramos convencer a nuestro lector de que, bajo las imágenes superficiales del agua, existe una serie de imágenes cada vez más profundas, cada vez más tenaces, no tardará en sentir, en sus propias contemplaciones, simpatía por esta profundización [...] Reconocerá en el agua, en la sustancia del agua, un tipo de intimidad [...] Tendrá que reconocer que la imaginación material del agua es un tipo particular de imaginación $[\ldots]$ el lector comprenderá por último que el agua es también un tipo de destino, ya no solamente el vago destino de las imágenes huidizas, el vano destino de un sueño que no se consuma, sino un destino esencial que sin cesar transforma la sustancia del ser (Bachelard, 1978: 15) (La cursiva es mía).

En la poesía de Zurita, con su acuoso mundo desbordado y desbordante de ríos que se arrojan desde el cielo, cascadas, mares, rompientes, cordilleras, cumbres flotantes, mares que son el cielo, cielos que son el océa-

\footnotetext{
${ }^{3}$ Es el verso con que concluyen los tres poemas de "Verás ciudades de agua", sección previa a "Las ciudades de agua" en Zurita, que no se encuentra sin embargo en el poemario de 2007 (Las ciudades de agua).
} 
no, cielos "espumeando de amor sobre las montañas", y ciudades de agua, bien puede afirmarse que "la imaginación material del agua" es "un tipo particular de imaginación", a través de la cual accede a una muy particular intimidad, que le permite el acceso a las profundidades del yo en constante transformación. Es a través del agua que el poeta proyecta la multiplicidad de imágenes de un "yo" quebrado en recuerdos superpuestos que parecen reconstruirse, además, en "un tipo de destino". Hacia él apunta el viaje del pasado al futuro que en los poemas se construye mediante una poética de la materia, del agua pero también del resto de elementos naturales, el fuego, el aire y la tierra, de origen en Bachelard. Esta poética de Zurita tiene pues su plasmación en la "ensoñación de la materia", interpretación principal del pensador francés 5 . El agua hace surgir en Zurita un imaginario concreto sobre dos conceptos materiales de diferente taxonomía y procedencia como son el agua y la ciudad. Emerge entonces también un imaginario del espacio, así como una geografía urbana formando parte de la geografía elemental del universo y del yo que lo representa.

Resta una última reflexión, sobre el plural del título: Las ciudades de agua, que pudiera sugerir que en cada poema encontraremos poetizada una ciudad distinta. Efectivamente aparecen varias ciudades a lo largo de los poemas: Santiago, Valparaíso, Buenos Aires, México, Berlín... Sin embargo, la idea de "ciudades de agua", en plural, aparece en realidad en cada poema como visión dentro del espacio de una ciudad concreta, o incluso en un espacio como el desierto. Si pensamos en esa proyección de imágenes superpuestas que los reflejos producen y en la fragmentación de visiones urbanas que generan, el plural del título adquiere toda la dimensión de lo líquido, que irradia en sí mismo una pluralidad de sentidos determinante del complejo universo poético construido en "Las ciudades de agua".

Desde esta perspectiva de imbricación entre lo líquido, la imaginación, y la multiplicación de imágenes y sentidos, producida poéticamente en y desde el espacio de la ciudad, Zurita traslada al ámbito poético-urbano algo que, en realidad, pertenece a la tradición literaria y artística de todos los tiempos: el mundo de la imaginación tras el espejo, esa otra realidad imaginaria que el reflejo abre a la mirada y que ha sido motivo obsesivo

${ }^{4}$ Último verso del Canto de los ríos que se aman (1997).

${ }^{5}$ En un ámbito teórico, véase también el sueño de la materia en Aldo Trione (1989) y en Luis Puelles Romero (1997). 


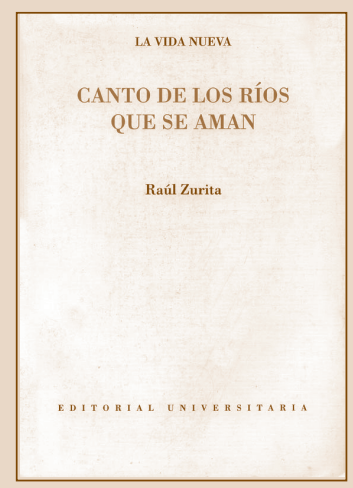

de búsqueda en la historia del arte ${ }^{6}$. Como veremos, en la poesía de Zurita tal motivo será interiorizado para la construcción de un mundo urbano transmutado por la poética de los espejos, del agua y por tanto, también, de la naturaleza.

De hecho, Zurita ya había retomado el motivo del reflejo en los espacios de la naturaleza, y así lo hace también en los de la ciudad, desde un ángulo que resulta inédito en la literatura urbana. Se trata de un enfoque que nos descubre otra "ciudad invisible", distinta a las que Italo Calvino trazó en Las ciudades invisibles (1972). Zurita, ojo avizor, penetra en otra ciudad aparentemente invisible: la escondida en los reflejos que la descomponen y la diluyen, convirtiéndose en esas "ciudades de agua" a través de las cuales el poeta entra en las profundidades del ser. Su ojo hecho de poesía descubre un mundo urbano en el que esos reflejos regalan a la mirada atenta el mundo visto desde ese otro ángulo; una nueva mirada que permite ver el otro lado de las cosas, teñida de con todas las claves que conforman su obra poética previa, absolutamente acuosa en las potentísimas imágenes de la naturaleza chilena y que, ahora, reaparecen en el espacio de la ciudad. Entre esas claves el agua es un elemento esencial, poetizado de modo coincidente con las ideas de Bachelard: "materia irracional", "materia atormentada", "materia misteriosamente viva" $(1978,24)$ :

El agua, agrupando las imágenes, disolviendo las sustancias, ayuda a la imaginación en su tarea de desobjetivización, de asimilación. Aporta también un tipo de sintaxis, una unión continúa de las imágenes, un dulce movimiento de éstas que hace levar anclas a la ensoñación aferrada a los objetos (1978: 25).

Así es, por ejemplo, el Canto de los ríos que se aman, "una unión continua de imágenes", de "torrentes golpeándonos", de escarcha, de "ríos que se lanzaban mordiéndose", del "caudal de todos estos años / destruyéndonos en sus brazos", del "mar que cae / bramando repiten las aguas del alto Biobío crecidas / derramándose", de "cauces que se nos vinieron al cielo de los ahogados", de "ríos que se arrojaron sobre este mundo". Y concluye el

\footnotetext{
${ }^{6}$ Basta recordar de la historia de la pintura el "Narciso" de Caravaggio, "Las Meninas" de Velázquez, los cuadros de Escher dedicados al mundo de lo líquido y los reflejos ("Ojo", "Mano con esfera", "Tres mundos"...), "El espejo falso" de Magritte, o la réplica de Dalí a "Las Meninas", en su "Dalí de espaldas pintando a Gala de espaldas eternizada por seis córneas virtuales provisionalmente reflejadas en seis verdaderos espejos", por mencionar solo algunos ejemplos paradigmáticos.
} 
poema: "pero por qué el / mal les volvemos a decir nosotros los ahogados del amor / flotando sobre los Andes suspendidos preguntándoles". Y "los paisajes se amontonaban llorando" (Zurita, 1997: 88).

Con la corriente de esta agua "atormentada y misteriosamente viva" poetizada desde el paisaje chileno, Zurita llega a las ciudades, y el agua, allí, tendrá la función que con tanta lucidez explicó Bachelard: la de "empeñarse en hallar, detrás de las imágenes que se muestran, las imágenes que se ocultan, ir a la raíz misma de la fuerza imaginante"; efectivamente, "desobjetivizar" la realidad (1978: 9).

\section{PARA UNA PROPUESTA DE LECTURA DE LAS CIUDADES DE AGUA}

El Poema 1 de la sección "Las ciudades de agua" discurre a través de una clara oscilación entre el escenario urbano y el "teatro urbano" (es decir, el espacio que protagonizan sus moradores ${ }^{7}$ ), dentro de un campo semántico dominado por el espejo y el reflejo, generadores de la idea de "ciudades de agua" en los sentidos ya propuestos:

Enteras de agua, las ciudades subían cubriendo el cielo / y los millones de puntos de luz de las ventanas de sus / rascacielos se espejeaban, como si fuera el mar, en la / inmensa plataforma del amanecer. No quise despertar / a mi compañera de cuarto y recordé que habíamos / discutido la noche anterior. Me había dicho que ya / estaba viejo para ciertas cosas y me indispuse. El / televisor había permanecido encendido y me asomé / con el torso desnudo a contemplar la calle. / ... Eran infinitos puntos de luz / ondeando sobre el agua. La desperté. Su cara se / reflejaba en el enorme estanque del cielo. ¿Eres tú? (Zurita, 2012: 643) ${ }^{8}$.

El ya comentado plural del título aparece aquí en "las ciudades de agua flotando encima del amanecer". La superposición de escenas que los reflejos intensifican se produce también de forma cinematográfica, y se desarrolla como fluctuación entre las visiones urbanas que se proyectan desde la ventana a la escena que sucede en el interior de la habitación, que nos llega a través del recuerdo de quien la está relatando. El espacio urbano se cons-

\footnotetext{
${ }^{7}$ Marco este tránsito con negritas, y con cursiva las palabras constitutivas del campo semántico del reflejo.

${ }^{8}$ Cito siempre el capítulo "Las ciudades de agua" a partir de su reproducción (que incluye algunas variantes) en Zurita (2012), indicando en adelante la página entre paréntesis.
}

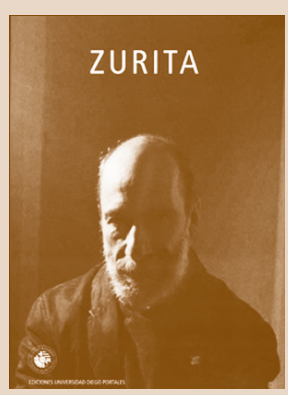


truye así en un amanecer lluvioso cuya imagen no sólo refuerza la tristeza de quienes la protagonizan sino que se funde con ellos a través de la humanización de la ciudad metaforizando al ser amado: las ciudades de agua, en el inmenso cielo de lluvia, formando "el contorno de una mejilla. De una mejilla con lágrimas"; una personificación que comienza en los versos precedentes: “... Las líneas de luz de los rascacielos suspendidos / habían comenzado a ensancharse y la imagen se había / vuelto transparente como si fueran lágrimas corriendo / sobre una inmensa mejilla. Había llorado..." (643). Vemos aquí esa desobjetivización de la realidad planteada por Bachelard a partir del agua, como materia que permite acceder a realidades ocultas del ser en su más profunda intimidad.

El poeta nos conduce, con su mirada lanzada por la ventana de un edificio, desde la imagen exterior de los rascacielos entre la lluvia, hacia la visión interior de ese paisaje que, a través de la comparación ("como si fueran..."), se convierte en un paisaje interior y, finalmente, en la representación misma de la imagen de la persona amada, llorando. Y desde la ciudad convertida en "una mejilla con lágrimas", un giro último nos conduce al que considero que es tema principal de la obra poética de Zurita, que se cifra, en realidad, en la humanidad toda, si bien a ella el poeta llega siempre desde lo individual, lo real o lo histórico9. De ahí el título de su último libro, Zurita, que lejos de cualquier egolatría, debe interpretarse como el camino que le permite profundizar en lo humano, desde el propio ser en su individualidad, tal y como el poeta ha planteado en diversas ocasiones ${ }^{10}$. Este salto (de lo individual a lo colectivo) se produce también al final de este poema cuando vemos que, al acercarse supuestamente a despertar a su compañera, "millones de figuras de agua / se iban dibujando en las ciudades suspendidas, millones / de rostros, de lágrimas, de bocas contraídas que se /fundían unas en otras" (643). De la escena particular, y a través de este mundo confuso de reflejos que la lluvia y las ciudades de agua generan y potencian, el poema nos lanza una inédita imagen urbana: la de una

${ }^{9}$ Un libro principal en este sentido es el Canto a su amor desaparecido, que, como apunta Edmundo Garrido Alarcón, supera "la coyuntura espacio-temporal de los abusos de la dictadura en Chile para erigirse en un canto universal de dolor y memoria...” (Garrido, 2008: 168).

${ }^{10}$ En Los poemas muertos también encontramos, en el titulado "Una imagen", una idea esencial en ese mismo sentido, al reflexionar sobre la "escritura celeste" que inauguró en Anteparaíso (1982), y desarrolló en los murales en el cielo de La vida nueva (1994): "Pero no, la muerte es un hecho inminente y me emociona saber que yo seré el único que habré visto esos dibujos en toda su demencia y belleza. Es ese trazo final de la muerte, su composición, que deshará las figuras dibujadas en el cielo igual que el viento, pero que las deshará dentro de mí, sin que ningún otro las vea, lo que paradójicamente me hace sentir que todos somos uno" (Zurita, 2006: 9). 
nueva muchedumbre o "multitud" (como denominaron Baudelaire y Poe a la aglomeración de personas en el espacio de las ciudades modernas ${ }^{11}$ ), vislumbrada en el poema de Zurita de un modo absolutamente particular pero íntimamente vinculado a su poesía previa: una muchedumbre urbana que, en lugar de encontrarse en las calles o en otros escenarios urbanos, se eleva hacia el cielo de la ciudad. Años atrás Zurita ya había poetizado las multitudes, pero sobre las cumbres de los Andes en el Canto de los ríos que se aman, de La vida nueva (1994), del que podemos recordar "La sinfonía de la aurora": "Y nos acabábamos en el cielo / amanecidos, borrosos de / nubes, oh si mira, como una / sonata vaciándose en la aurora / [...] / Como murales en el cielo como las muchedumbres de los / hombres que se erizaban sintiendo los ríos penetrarlos" (Zurita, 1997: 117).

Ese mural en el cielo, pintado con versos pero también con la ilustración que los acompaña (tanto en la edición de La vida nueva como en Canto de los ríos que se aman ${ }^{12}$ ) se poetiza aquí de nuevo en "millones de figuras de agua", que aparecen ahora sobre estas "ciudades suspendidas", formadas por rascacielos de la gran cosmópolis convertidos, finalmente, en el "enorme estanque del cielo": "Su cara se reflejaba en el enorme estanque del cielo". Bien podría ser ésta una imagen poética interior del rostro de la amada en ese cielo transmutado en estanque, que ya había creado en La vida nueva: "Vi de nuevo tu cara sobre el cielo" (395). Pero si la leemos en relación a la propuesta antes trazada sobre las "ciudades de agua", y teniendo en cuenta que el rostro no es visto en el cielo, sino que lo que se ve es su reflejo en el estanque del cielo, podemos proponer otra lectura: mientras que el cielo nada refleja, los edificios sin embargo reflejan el cielo, de modo que los edificios se estarían poetizando como ese "enorme estanque" que en el poema no sólo refleja el cielo sino también el rostro de la compañera ("su cara se reflejaba en el enorme estanque del cielo"), a quien, cerrando el poema, se interroga: “¿Eres tú?”.

Pero reparemos también en una interesante coincidencia: la interrogante “¿Eres tú?" nos retrotrae, una vez más, a un Zurita anterior, al del Canto a su amor desaparecido (1985), en el que, siguiendo la reveladora lectura, propuesta por Garrido Alarcón, del texto "como una configuración urbana" (2008: 161-171), el poeta ya había construido una ciudad: la ciudad de

\footnotetext{
${ }^{11}$ Edgar Allan Poe, en "El hombre de la multitud" (1840), Charles Baudelaire en Los pequeños poemas en prosa o El spleen de París (1869).

${ }^{12}$ Que conforma la parte central de La vida nueva y que Zurita publicó de forma exenta en 1997.
}

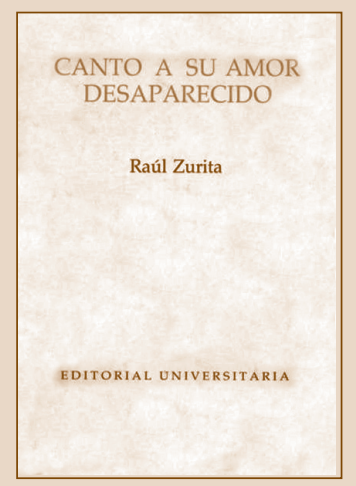


la memoria que es "el cementerio con las tumbas de los desaparecidos". Los dos últimos nichos concluyen con una pregunta muy similar, “ ¿Me llamas tú?", proveniente de una voz desde el interior de la tierra que surge al ser invocada desde el exterior. La respuesta que se da a esta pregunta al final del Canto... la retomo en la lectura del poema 10 de "Las ciudades de agua".

Antes, otros nueve poemas nos conducen a un pasado personal que se ofrece siempre desde la imagen urbana, invariablemente entre luces y reflejos; por ejemplo el Poema 2, que comienza con estos versos: "Suspendidas, las ciudades de agua emergían tendiéndose / sobre la aurora y los reflejos de sus avenidas parecían / enormes canales de luz estriando la amoratada / superficie del cielo" (644). De la imagen urbana pasamos a una superposición de recuerdos que se funden en el espacio de la escritura a través de un ir y venir del tiempo verbal pasado al presente; superposición que a su vez se construye mediante otra transformación de imágenes que se refuerzan entre sí en el Poema 3, que comienza: "He descendido hasta aquí porque mi vida es vacía" (645). La clara simbología del descenso (que evoca la bajada al infierno), se intensifica con la reiteración del "arriba", donde están siempre las "ciudades de agua", suspendidas, flotando, desde su primera aparición en el poemario, como símbolos de vida, de esperanza, como una redención, en el "Sueño 355 a Kurosawa"13. Este poema concluye con un rotundo "en ese entonces yo sufría", y la aparición de estas ciudades acuosas sobre el desierto, evidentemente como un espejismo, poetiza el agua (o sea, la vida), inundando la aridez del desierto. Una superposición que refuerza la idea de intercalación de capítulos vitales relatados en este libro. En tanto que espejismo, "las ciudades de agua" pueden ser también la esperanza, la ilusión de una "vida nueva":

${ }^{13}$ Resulta significativo que la primera aparición de estas "ciudades de agua" suceda, dentro del poemario de 2007, en el desierto: "Vi las primeras ciudades de agua camino al norte, / en Atacama. Estaban suspendidas en el cielo, como / gigantescos acuarios transparentes, y las líneas de luz / de sus reflejos se mecían sobre el suelo cubriendo por /completo la inmensa planicie ocre" (Zurita, 2007: 34).

Raúl Zurita, al ser preguntado por esta primera aparición de "las ciudades de agua" en el desierto, bastantes páginas antes del capítulo que lleva el título del libro (en la edición de 2007 aparece en la p. 34 y el capítulo "Las ciudades de agua" comienza en la p. 117), revela que este poema en realidad está escrito después de los poemas que forman dicho capítulo, pero que "tenía que ir antes como anuncio de la idea", es decir, que "son formas de anunciar algo que va a aparecer bastante más adelante", una "forma de poner énfasis adelantando pequeñas cosas que van tomando protagonismo". Véase la entrevista al escritor en "Canal Multimedia" del Centro de Estudios Iberoamericanos Mario Benedetti: http://web.ua.es/es/centrobenedetti/canal-multimedia.html Seminario "Raúl Zurita: un creador nos introduce en su mundo" (3a sesión). 
Era el año 1975, / a fines del verano, y por entonces yo sufría. Fue la / primera vez también que conocí un desierto. No me / sorprendió verlas, incluso diría que me dio una cierta / paz. [...] / A lo lejos se veían los dos volcanes y los reflejos de / la primera de ellas les imprimían a sus cumbres / nevadas un tono verdoso como el del mar. [...] (Zurita, 1997: $34)^{14}$.

Pero regresemos al Poema 3, que se iniciaba con el verso: "He descendido hasta aquí porque mi vida es vacía” (121). El descenso se produce a esa vida que "es" vacía, no que "está vacía”; verbo "ser” con el que se potencia la inmensidad de ese vacío ${ }^{15}$ que se repite a lo largo del poemario como un eje vertebrador. Al llegar a los poemas del capítulo "Las ciudades de agua", ese vacío se ve de repente colmarse y desbordarse del agua de esas ciudades que siempre están arriba, y que desde el Poema 1 remiten a un nuevo presente. Este se solapa constantemente con el pasado, en el que el vacío se expresa una y otra vez a través de imágenes urbanas: "He descendido hasta aquí porque mi vida es vacía. / Arriba las ciudades de agua han tomado el color / inenarrable de la primera mañana y sus contornos / brillan como lejanos planetas azulosos" (645). Y de nuevo vamos de este acuoso escenario urbano al teatro urbano (a sus protagonistas): "Habíamos / bajado con otros grupos en el día ya claro y al final / de las escaleras la estación del metro recién estrenado / se abría recortando sus paredes de azulejos y casetas /de boleterías sin nadie" (645). El descenso en esta vida que "es vacía” se expresa así a través de una imagen urbana: una bajada hacia un escenario subterráneo de la ciudad (metáfora de un viaje interior), y vacío, como es la imagen del laberinto del metro "sin nadie", en el que los azulejos funcionan como el agua espejeante que de nuevo permite la desobjetivización de la realidad propuesta por Bachelard:

\footnotetext{
${ }^{14}$ Estos paisajes, revela Zurita, son "paisajes mentales", "la naturaleza en movilidad", y añade que son "grandes telones que se van levantando con la pasión... con tu vida vas levantando los paisajes que ves... grandes telones en blanco que se van llenando con la pasión de vivir y son la suma de las miradas que lo han visto... los paisajes se levantan cuando tú los miras, están cargados de todos los ojos que lo han visto. Un poema es un acto real y definitivo. Del enfrentamiento final surge un poema”. Véase la entrevista al escritor en ibídem.

${ }^{15}$ Aparece así expresado por primera vez en el poemario en el tercer poema de los titulados "Cielo abajo" ("Tengo 52 años y mi vida es vacía"); un vacío que ya aquí viene a adquirir toda su dimensión desoladora a través de una imagen de ciudad arrasada, en este caso, Santiago: “... Aplastadas en la / planicie infinita del desierto todavía se pueden ver / las huellas de un puente roto y más acá las líneas / cuadriculadas donde estuvieron unas calles, unas / casas...” (17).
} 
Más abajo, el / color azul de los flamantes vagones se espejeaba igual / que un río en las baldosas del suelo. Mi hijo de un año / me aferraba el cuello y su pelo rojo muy largo, en / bucles, resaltaba en la pequeña cara blanca. La que era / entonces mi mujer llevaba una falda a crochet de / color violeta... (645).

Y del realismo de la escena, el poema nos conduce a la imagen onírica. El relato poético sitúa al lector ante un espacio citadino, que se ve finalmente impregnado de naturaleza en los últimos versos, a través de la comparación con el mar:

... Es un segundo;/ la imagen se hace añicos y ahora el pelo rojo se le / pegaba a la cara con el sudor, la saliva del chillido y / las lágrimas. Su chillido crece y veo que su pelo ha / comenzado a ralear. Le digo que aunque no escuche / nada, que aunque ahora no oiga nada se pasa, que ese / dolor se pasa. Yo le había rogado a ella con la misma / furia y arriba las nubes cambiaban de formas. La que / había sido mi mujer se granula en miles de puntos / igual que el mar sobre la inmensa pared vacía (645).

Concluye el poema con esta nueva construcción de un vacío sobre el que se proyecta la figura granulada de la mujer, y con la aparición de la imagen fantasmal que intensifica el vacío: “... Recuerdo que / los trenes se movían en silencio, un silencio irreal, / blanco, como el de las nubes altas cuando se desplazan" (645).

En los siguientes poemas de nuevo se poetiza la visión de la "ciudad de agua" como idea que funciona para la recuperación del recuerdo, como en el Poema 4:

Los infinitos reflejos de las ciudades de agua destellaban / ascendiendo y sus estelas parecían largos ríos blancos / deslizándose en la lividez del cielo. Recuerdas entonces / una calle que te parece conocida aunque no sabes su / nombre. Suspendidos en lo alto los inmensos edificios / se deshacen en un caserío ocre que remata en una plaza / cuadrada donde está el campanil y un poco más atrás / el río. [...]/ ...Ha caído la / noche y las ciudades de agua parecen gasas fosforeciendo / en la oscuridad. La que ahora recorres es muy antigua. / ... Tus padres también / se deshacen mirándote con pena. Arriba, como si fueran / inmensos acuarios transparentes, los rascacielos / destellaban doblándose en la curvatura azul del cielo (646).

Como vemos, los recuerdos se diluyen como las imágenes urbanas de contornos imprecisos, combándose, curvándose, deshaciéndose. La mirada 
sobre la ciudad líquida proyecta asimismo un recuerdo nebuloso y evanescente. $Y$ "las ciudades de agua" vuelven a aparecer aquí como "inmensos acuarios transparentes", los mismos que había imaginado el poeta por primera vez en el desierto. Como un haz de sentidos que se van hilando a través del poemario, grabando progresivamente en el lector imágenes que se refuerzan a través de la reiteración de procedimientos poéticos, el Poema 6 nos introduce nuevamente en un mundo de reflejos en el que descubrimos que el poeta ha empezado a escribir Las ciudades de agua en la gran cosmópolis, Berlín:

Has salido temprano. Los reflejos de las ciudades de / agua han tomado el color oscuro de los ríos encajonados / y ves entonces el puente. Tú estás sobre él. Tienes / diecisiete años y ella un poco menos. [...]/ ...Tú estás lejos / y yo he comenzado a escribir Las ciudades de agua / en Berlín. Sin embargo es cierto que has salido temprano, /que te encontrarás conmigo, que te perderé sin remedio (648).

De especial interés resulta también el final del Poema 9 , en el que se reitera el despertar en la ciudad, en Berlín, y se explicita la idea de las escenas superpuestas, que pueden ser recuerdos, fragmentos de vida yuxtapuestos, que encuentran una metáfora perfecta en las "ciudades de agua":

... Tratas de despertar. Me despertaré en una / ciudad de paso, helada, será Berlín. Le digo que parto en / dos días más y que esto puede ser una despedida. Me / habla de alguien que le hace falta. / La miras y tú también desearías decirle que te hace falta. / Hay infinitas escenas que viven y en una de ellas alguien / que podías haber sido tú siente el aire húmedo y helado / golpearle las narices (654).

Concluye este noveno poema con estos versos que destacan esa intercalación de tiempos y escenarios como andamiaje esencial de los poemas:

... Le dije también / que después de todo no dejaba de ser extraño ser chileno / y no ser un desaparecido. Regreso. En las barriadas las / manifestaciones empezaron al oscurecer y duraron varios / días. / Nos levantamos de la mesa y salimos a la oscuridad, las / noches se han vuelto más frías. Arriba, sobre todos los / amaneceres del mundo, las ciudades de agua brillaban (656).

Un final de poema en el que de nuevo Zurita nos lleva de lo particular chileno, de su hecho histórico más trascendental -el golpe militar del 73-a 
lo universal, cuando vemos que sobre todas las circunstancias históricas, las ciudades del mundo, "arriba", siempre arriba, siguen brillando.

El recorrido por la sección "Las ciudades de agua" concluye en el Poema 10, que cierra de forma circular la historia contenida en la misma, pues retoma el relato que se había quedado en suspense en el Poema 1 con la pregunta “¿Eres tú?”, y que ahora concluye, unas horas después de aquel amanecer:

Suspendidas, las ciudades de agua cubrían ahora por / completo el amanecer y las infinitas lineas de luz de sus / reflejos se entrecruzaban sobre la calle que ondeaba / suavemente, difusa, como si todavía no pudiese / desprenderse de la unanimidad de la noche. Recordé / entonces que mientras discutíamos la imagen muda del / televisor iluminaba tu cara como si fuera una estepa o un / planeta extraño y que nuestras voces retumbaban como si / vinieran de lejos. Luego vi que dormías, o era yo, no lo /sé (657).

La confusión que en este momento se hace patente alerta sobre la posibilidad de que "ella" en realidad se hubiera marchado tras la discusión del Poema 1, y que el universo de reflejos del amanecer produjera la ensoñación o la ilusión de la persona amada dormida. Sigue el poema enfocando una escena cotidiana en la que no sabemos si la segunda persona es "ella" o el "yo" lírico: "Ahora corres el cobertor de la cama y te levantas. / Pones el calentador de agua, te preparas un café y miras / por la ventana hacia la calle. Antes de salir me dices que / puedes adivinar lo que yo sueño por las noches y que eso / es prueba de tu amor" (657). Y continúa el poema con una construcción de la ciudad a través de metáforas de la naturaleza intensamente identificativas de su poética previa, que ahora, de forma inédita, viran por un nuevo derrotero para filtrarse en el espacio de la urbe y denotar sus mismas convulsiones, tensiones, ondulaciones, vibraciones... que son las de sus mares, sus ríos torrenciales, sus cauces anegados, siempre derramándose. Es, en definitiva, la naturaleza viva convertida en ciudad:

... Caminas, llegas a la esquina y ves / arriba los rascacielos que se van doblando igual que / rompientes. Avanzas mirando los números, pero al rato / te detienes, vuelves sobre tus pasos y tu cara se espejea / en las ciudades de agua agigantándose. Cruzas una de las / ondeantes calles y sus olas te reflejan multiplicándote en / incontables puntos de luz, en incontables fragmentos que / vibran cada vez más fuerte sobre las encrespa- 
das / superficies de agua. La imagen del televisor iluminaba tu / mejilla mojada y eran / millones de planetas anegados, de / estepas sumergidas, de praderas chorreantes. Finalmente / reconoces el edificio que ondea furiosamente y ves las / ladeadas lagunas, los inclinados lagos del cielo / deslizándose como lágrimas. Entras. Subes saltando las / escaleras y llegas a la puerta. La golpeas. ¿Eres tú PW? (657).

Tras esta carrera desesperada por esta ciudad hecha de naturaleza, en la que se retoma la escena del llanto, poetizada ahora con la bellísima imagen de los "lagos del cielo deslizándose como lágrimas", el poema, y "las ciudades de agua", se cierran con la reiteración de la pregunta del Poema 1, a la que ahora se añaden unas siglas: “¿Eres tú PW” (Paulina Wert), y también la respuesta final: "Sí, dices" ${ }^{16}$. Respuesta que confirma la ensoñación en el Poema 1 respecto a la presencia del ser amado en la habitación primera. Ahora descubrimos que "ella" en realidad se había marchado tras la discusión, y que la reencuentra en otro lugar de la ciudad cuando ya ha concluido el amanecer. Este "Sí, dice" (que adquiere la rotundidad denotada por su aparición a solas en una página en blanco) es exactamente la misma respuesta que, al final del Canto a su amor desaparecido, se dio a la pregunta de la voz del nicho "¿Me llamas tú?": "Sí, dice”, que aparece repetida varias veces en respuesta a preguntas alusivas a la memoria histórica, y que dan paso, finalmente, a una "invocación a la desaparecida para que cante" (Garrido Alarcón, 2008), concluyendo el libro: "Así sonó entonces el Canto / a su amor desaparecido".

El paralelismo de ambos finales, con la coincidencia en la respuesta "Sí, dice", resulta revelador. Si en el Canto... efectivamente se construye una necrópolis a través de un "canto fúnebre y de lamentación del sobreviviente en el contexto de un duelo" (Garrido, 2008), en los poemas que componen "Las ciudades de agua" el poeta nos sitúa en ciudades de vida -pasada y presente-, augurales de una "vida nueva", que se abre ante el reencuentro con la mujer amada (P.W.) al final del relato, cuando ésta responde a la invocación del poeta, ya no desde el interior de la tierra, sino desde la vida misma, con este rotundo: "Sí, dice"; respuesta con la que el poeta lanza uno más de los hilos que hacen de su obra, efectivamente, una "obra en progreso".

\footnotetext{
${ }^{16}$ En Zurita aparece con la variante "Sí, dice”.
} 
Para concluir, cabe señalar que en Zurita encontramos también otras ciudades diversas, si bien la idea de "ciudades de agua" se construye a lo largo de todo el libro. Así por ejemplo, en el poema "Los Españoles 1974" (hacia la mitad del libro) aparecen con un sentido que resulta determinante:

El paso del mar ha comenzado a ascender y arriba, / recortándose entre los dos / murallones de agua que / lo flanquean (...) las cataratas se precipitan mundo abajo, infinitas, / destellando. Son las cataratas del Pacífico. La / neblina que forman sus pulverizadas espumas sube / fundiéndose con el cielo estrellado y lloro mirando / mis restos flotar en la niebla. Me digo entonces que / tú y yo nos encontraremos en los próximos cantos. /Que nos encontraremos en las ciudades de agua, / (...) Te arropas entonces girando en la cama y dormida / buscas a tientas mi mano mientras que al fondo, / a sólo cuadras de nuestro sueño PW, las cataratas / del Pacífico se precipitan mundo abajo, bramando (Zurita, 2012: 389).

Y Bachelard había escrito: "Desaparecer en el agua profunda o desaparecer en un horizonte lejano, asociarse a la profundidad o a la infinitud; tal es el destino humano que busca su imagen en el destino de las aguas" (1978: 25). Tal es el sentido de las "ciudades de agua", que se amplifican en Zurita con "ciudades de sed", "ciudades arrasadas" o "ciudades trituradas", generando nuevos sentidos urbanos de esta nueva poética de la ciudad que Raúl Zurita, con inobjetable originalidad, ha creado desde el libro de 2007 (Las ciudades de agua) hasta Zurita (2011).

\section{REFERENCIAS}

Bachelard, G. (1978 [1942]). El agua y los sueños. México: F.C.E.

Bauman, Z. (2002 [2000]). Modernidad líquida. Buenos Aires: F.C.E.

Delgado Ruiz, M. (1999). Ciudad líquida, ciudad interrumpida. La urbs contra la polis. Medellín: Editorial Universitaria de Antioquía.

Garrido Alarcón, E. (2008). "Construir una ciudad para la memoria: Canto a su amor desaparecido de Raúl Zurita". Revista de Filología Románica, anejo VI, 161-171.

Puelles Romero, L. (1997). La estética de Gastón Bachelard. Cádiz: Universidad de Cádiz.

Rovira, J. C. (2011). “Zurita, obra en progreso". Alonso, Ma N. y Alemany, C. (Eds.), Diálogos para el Bicentenario (pp. 81-103). Concepción: Editorial Universidad de Concepción. 
Trione, A. (1989). Ensoñación e imaginario, la estética de Gastón Bachelard. Barcelona: Tecnos.

Zurita, R. (1994). La vida nueva. Santiago de Chile: Editorial Universitaria.

Zurita, R. (1997). Canto de los ríos que se aman. Santiago de Chile: Editorial Universitaria. . (2006). Los poemas muertos. México: Ácrono Producciones. . (2007). Las ciudades de agua. México: Ediciones Era. . (2012 [2011]). Zurita. Salamanca: Editorial Delirio. 